\title{
Travelling and writing between England and Nigeria. An interview with Noo Saro-Wiwa
}

Roberto Zaugg and Noo Saro-Wiwa

\section{(2) OpenEdition \\ 1 Journals}

Electronic version

URL: http://journals.openedition.org/edl/2496

DOI: 10.4000/edl.2496

ISSN: 2296-5084

Publisher

Université de Lausanne

\section{Printed version}

Date of publication: 15 December 2017

Number of pages: 145-154

ISBN: 978-2-940331-66-6

ISSN: 0014-2026

\section{Electronic reference}

Roberto Zaugg and Noo Saro-Wiwa, «Travelling and writing between England and Nigeria. An interview with Noo Saro-Wiwa », Études de lettres [Online], 3-4 | 2017, Online since 15 December 2019, connection on 20 December 2020. URL : http://journals.openedition.org/edl/2496 ; DOI : https:// doi.org/10.4000/edl.2496

\section{(c) Études de lettres}




\section{TRAVELLING AND WRITING BETWEEN ENGLAND AND NIGERIA. AN INTERVIEW WITH NOO SARO-WIWA}

Travelling is at the very heart of Noo Saro-Wiwa's work as a writer and, in many ways, of her life. Born in Port Harcourt, she grew up in England and studied in London and New York. She has worked as a journalist (The Guardian, The Independent, The Financial Times, The Times Literary Supplement and Prospect magazine...) and as a travel guide author (Lonely Planet, Rough Guide). In her award-winning first book, Looking for Transwonderland. Travels in Nigeria (2013), she offers fascinating insights into the diversity and contradictions of Africa's most populous country, while narrating a very personal journey through her homeland and her family's history. On April 6, 2017, she gave a talk at the University of Lausanne, discussing the persistence of biases affecting the representation of Africa in literature and journalism as well as the many challenges one faces when writing about this continent in the 21 st century.

RZ: In Looking for Transwonderland you offer a deliciously humorous description of summer holidays during your childhood. At that time, you were living in "leafy Surrey, a bountiful paradise of Twix bars and TV cartoons and leylandii trees". From there, every summer you were sent to your "unglamorous, godforsaken motherland" - a small village in the Niger delta - to regenerate your spirit in close contact with your ancestral roots. When I read this, last summer, I had to laugh, because at that very moment I was myself spending some family holidays with my son... in the godforsaken village of my ancestors in northern Italy. I had to ask myself: Why is cultivating "home" and transmitting an emotional relationship to specific places so important to many people? Is this a cultural obsession in our highly mobile and globally entangled societies? 


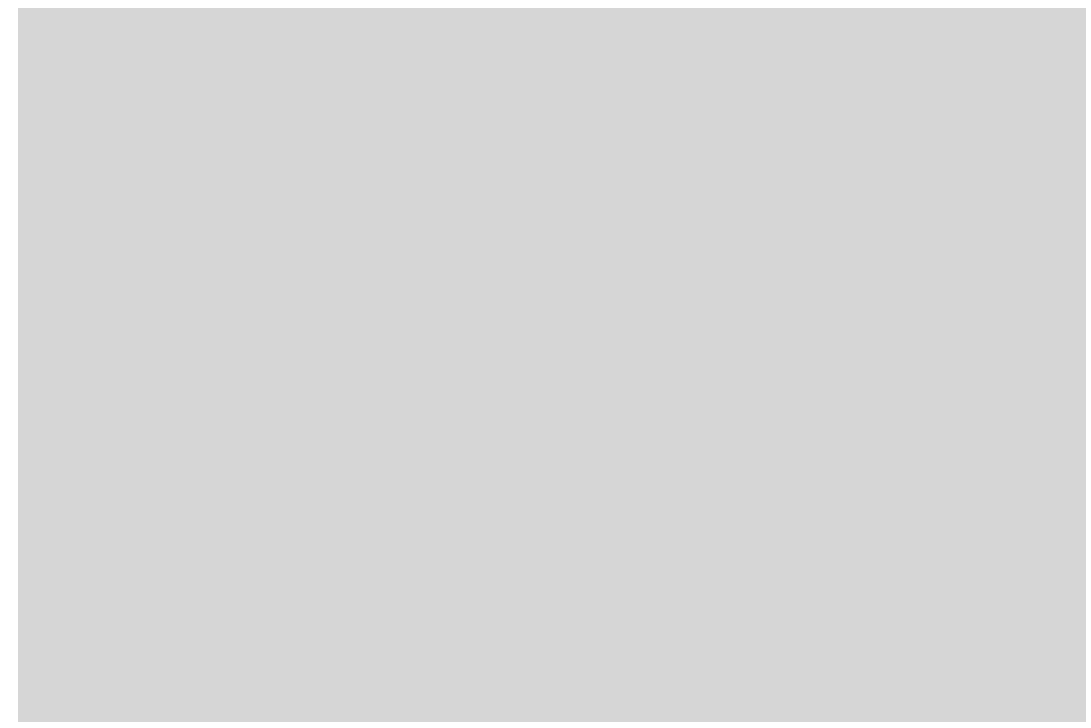

Noo Saro-Wiwa at the University of Lausanne (6 April 2017)

(C) Gustave Deghilage

NSW: I think home is an emotional thing as well as a physical thing. The definition of "home" depends on whether you are talking from an affective, practical or political perspective. When people migrate to other countries, they are often not one hundred per cent accepted there. So it feels good to have that grounding, to be aware of where you have come from. For me, if I had been taught by my parents to believe that I was British when we came to England, I think I would have found it much harder to live in the UK as a member of a minority. Because when you feel you are just an expat, you do not worry about the lack of black faces on TV. You are thinking: "Well, this is England".

In Surrey in those days, we were the only black family. As a young child I remember seeing people of West Indian descent describing themselves as British. I didn't understand that. I thought: "You can't be British, you're black". When you are an outsider, in some ways it is easier if you perceive yourself as an outsider. You are not offended by your lack of representation on television or wherever, and you just get on with it. So yes, I feel very lucky that we have this place - this village in the Niger delta - that I can call "home", even though I would not ever want to live there. Psychologically it is important to be rooted in that one place. 
Having that one foot outside is about not putting all your eggs in one basket. A lot of people who have migrated to other countries - or who experience discrimination in the land they were born and raised are looking for another place, another basket to put their eggs in. Some African-Americans have tried to do that for years, for example by giving themselves invented, exotic names. They do not want to fully buy into US mainstream culture, because they feel that that mainstream society rejects them.

RZ: In your book you recall a discussion you had on the campus of the University of Ibadan with the president of the Student Association, Faith Odele, in which she was arguing: "It seems that Nigerian writers who make it are from the diaspora. [...] People don't seem to want to read books by Nigerians living in Nigeria". Indeed, over the last decade, authors from the Nigerian diaspora have attracted the attention of a broad international readership. Books by authors such as Chimamanda Ngozi Adichie, Teju Cole, Tayie Selasi and yourself have been translated into French, Italian, German and other languages. By contrast, the best known Nigeria-based authors are still those of our parents' generation, the generation which witnessed colonialism and independence - men like Chinua Achebe, Wole Soyinka or your father, Ken Saro-Wiwa while younger Nigeria-based authors seem indeed to struggle to attain the same visibility with their published books. Isn't it paradoxical that today - in an age of digital communication - space should matter so much and African-based authors should seem to have more difficulties to connect themselves to global book markets than in the years of decolonization?

NSW : I think African-based authors can and do connect themselves to global markets as much as before. Quite a few African writers have been shortlisted for Western literary prizes, such as the Man Booker Prize and the Bailey Prize. But while our expectations of access have grown since the 1960s (thanks partly to the internet), the window of opportunity hasn't expanded as much as we would like.

Let's not forget that authors in most countries in the world cater to their local markets. The lack of a large local market in Africa means that writers from the continent have to seek recognition in the West, which is already a crowded scene. 
Concerning our parents' generation, their success is partly due to the fact that people like Wole Soyinka, Chinua Achebe or my father were educated in Nigeria, but the education back then was good quality, it was on a par with the education in England. The University of Ibadan, where these authors studied, was established as one of the colleges of the University of London, and the faculty were British. These guys essentially received an English academic education. Their grammar was perfect and they were deeply acquainted with novels as a textual genre. In a sense, they were a part of that Western literary tradition, even though they would not necessarily describe themselves in that way.

The works of this founding generation have become classics. I am not the biggest reader in the world, but novels like Chinua Achebe's Things fall apart are really important works. Achebe occupies a very particular place in describing the exact moment when Western Christian civilization met with African civilization. It is quite difficult to replicate what he did.

Today, people in Nigeria of course still have a great imagination and talent. But over the last decades education standards in Nigeria have slid pretty badly. On the one hand, this has had a negative impact on English writing skills among the population. I see lots of great story ideas but they are poorly executed. On the other, many talented Nigerian students leave the country to attend universities in the West and, once they are there, many do not come back to Nigeria to live permanently. So African literature is thriving in some ways, but in the diasporic sense. However, indigenous publishing houses such as Cassava Republic are trying to change this. They publish African literature but use their UK imprint to bring literature from the continent to an international audience.

RZ: Migration, multiple belongings, alienation and discrimination, as well as complicated relationships to one's own country of origin are central themes of recent bestsellers such as Americanah, Looking for Transwonderland or Ghana must go. These topics are highly relevant not only to the Nigerian diaspora, I think, but more generally to a European society in which such experiences are increasingly widespread. Is the success of diasporan literature perhaps also fuelled by specific expectations and cultural sensibilities among contemporary readers in the West? And what role do Western publishers play in this context? 
NSW: There is big debate in the literary community about the influence of Western publishers on African literature. Many complain about "misery porn", for example, that is the demand-driven centrality of tropes about misery and violence in books on Africa. But to be honest, there is really a lot of tragedy in Africa. If I were to write a book based on my family history, there would be a lot of death and murder and all sorts of things. In any case, one should not make sweeping conclusions about the reasons which influence writers and publishers. Most African authors are not tactical. As an author, you generally just write what you want to write, and then you see what happens when the manuscript gets to the publisher. And Western publishers are not all the same. Some are making a conscious decision based on commercial expectations. Other publishers are genuinely interested in African literature. And sometimes the decision to publish a book can be based on one person's individual taste or agenda. However, I would say it's true that literature can be subject to trends, and cultural identity has certainly been a big topic over the last decade or two.

RZ: Your book combines multiple temporalities: the time of your travel intersects with the time of your life and with that of your family's history, as well as with Nigeria's present and with its recent and remote past. During your journey you made a trip to the coastal town of Badagry, in southwestern Nigeria, where you visited the Slave Relic Museum. Paradoxically, this museum is "owned by local Chief Mobee, descended from the long line of chiefs who had presided over the slave trade" for centuries. The history of slavery and the slave trade connects together - in a painful and politically unresolved way - Europe, Africa and the Americas. It is a chapter of a shared history. But the memories of this entangled past remain deeply divergent.

NSW: I did not go to school in Nigeria, so I cannot speak with any authority on it, but I do not think slavery occupies a major place in the school curriculum. Collective memory is very foggy when it comes to Nigeria's slave history. I went to the Cross River, this gigantic river that goes deep into the hinterland in south-eastern Nigeria. So many enslaved people were forced down that river. It is a major part of history, but you would not know from being there, apart from that small plaque indicating that this is where slaves were transported. In Nigeria 
there aren't many public memorials showing how these aspects of the past connect with the present.

A lot of Nigerians understand slave history through the American experience: they hear about what happened in the US, how slaves were treated there and the discriminations their descendants still face in nowadays. They feel a connection to African-Americans based on their shared blackness. They know that the ancestors of many AfricanAmericans came from modern-day Nigeria. But the African side of that history is far less documented and so it gets forgotten, like so much of African history. People left Africa and so did the paperwork: the documents and the artefacts are in Europe and America. And the history of indigenous slavery is hardly a topic of political debates and memorial initiatives in Nigeria.

RZ: You repeatedly express your anger about the state of museums and historical monuments in Nigeria, the lack of funds for cultural institutions and - in a certain sense - the absence of a spirit of national pride among political elites. You connect this question with the controversial debate about looted African artworks which are nowadays in Western collections. On this behalf, you quote the philosopher Kwame Anthony Appiah - according to whom national governments cannot be regarded as actual owners of historical artworks, but should rather be considered as "trustees for humanity" - and you add that, given the current situation of Nigerian museums, "a treasonous corner of my mind made peace with the foreign custody of some of our antiquities. At least they're guaranteed better security and maintenance in museums abroad". As you know, this argument about security is often used by Western institutions to resist claims for restitution. With regard to the current controversy over an ancient Benin bronze cockerel held by the University of Cambridge, Prince Edun Akenzua of the royal family of Benin has recently stated that "it is like tracking down a thief who has stolen your car, only for him to tell you that you can't have it back because there is a risk it might get stolen again" ${ }^{1}$.

I. Quoted in "Cambridge under pressure to return looted Benin bronze cockerel”, The Telegraph, 8 October 2016, <http://www.telegraph.co.uk/news/2016/10/08/ cambridge-under-pressure-to-return-looted-benin-bronze/>. 
NSW : The Cambridge case is different, because that is not a museum as such and primarily because there has not been any agreement between the Benin royal family and Cambridge. For me, the reason I agree with the Nok terracottas being in the Musée du Quai Branly is that there was an agreement made between the Nigerian and the French government. These artefacts do belong to Nigeria; they are just on a long-term loan. More people would see the Nok terracottas in Paris. Nearly no one goes to museums in Nigeria. When I visited museums in Nigeria, I was often the only person in there. People, even Nigerians themselves, rarely visit them: there are just school groups who go there and that's it. For me it is really a practical question: I want the world to see Nigerian artworks, and if they get more exposure in Europe, then so be it. But for me, the fact that they actually do belong officially to Nigeria, puts my mind at ease. That is why the Cambridge issue is separate.

RZ: In "A time to lie", a short story you have published in 2016 in $A$ country of refuge. An anthology of writing on asylum seekers, you reflect on what travelling means for different people in different contexts. You pick up the statement by a British holidaymaker who told a BBC reporter that "it was the worst journey of our lives"... because a group of refugees trying to cross the Calais tunnel had caused a delay of the Eurostar train she was travelling on. This discrepancy is at the very heart of mobility in the 21st century: for middle-class Europeans, taking a flight to Morocco or Dakar is no big thing, neither in economic nor in legal terms. At most, we risk being annoyed by some delays. For most Africans, Europe is a territory which can only be reached by investing big sums of money and by risking their lives. This asymmetry is so blatant that we have largely got used to it, nearly considering it as "natural". Although, of course, it is the result of man-made borders, of politically enforced obstacles.

NSW: There are so many Nigerians who would love to have a passport that lets them move freely - and they don't. I'm so lucky and I feel privileged to be able to travel like that. I did nothing to earn this, but I have that sort of protection. This little document gives me that protection. I did not apply for UK citizenship until I was nineteen. When I first started travelling I was eighteen and I still had a Nigerian passport. That is pretty much what prompted me to get a British passport, because I 
was suddenly confronted with what it means to try to see the world with African documentation. Having this UK passport means you can visit so many places. When I arrive at an airport immigration checkpoint, I can see how they look at me. They see an African, and for some of them you can tell they do not trust you. But then you present them with this document, and so they have to let you through. It is very strange.

RZ: Looking for Transwonderland is the story of the rediscovery of your native land: a retour au pays natal, to say it with Aimé Césaire. Your journey is narrated as a path which allows you to re-appropriate your country - or let's say, one of your countries - and at the same time as an experience which repeatedly leads you to acknowledge differences between yourself and the surrounding mentality, be it on behalf of gender-based expectations or because of the centrality of religious faith in everyday life. What, among other things, makes your book so rich is precisely your constant reflections upon these perceived differences. In relation to this, I would be curious to know if there have been fundamental differences with regard to the way readers have reacted to your book, in Nigeria and in Europe.

NSW: For some reason, Italian readers seem to understand where I am coming from: they draw parallels between my story and their own history and experience as migrants. With Nigerians, as far as I can tell, you get people who really love the book because their situation is just like mine: Nigerians living outside who, for example, take issue with the religiousness in our home country. Then you get others who feel that, as a Diasporan, I should not be writing about Nigeria and exposing Nigerian problems to a Western audience. To me, this makes no sense: Nigeria's problems are constantly discussed, both in newspapers and online. Everyone talks about corruption, about oil spills in the Niger delta, about sexism. Some commentators feel that it's the truth, but they don't want me to discuss that truth. It is a double standard.

There is also a fear of representation, which is rooted in how the media was organised in the past: some Nigerians feel that a book like mine will become the main source of information about Nigeria. Back in the 1990s they would have had a strong case to say that my book has really influenced people's perceptions of Nigeria. But now it is not the case. In the age of internet, if someone wants to google something about 
Nigeria, my book will not be the first thing that comes up. I think some people overstate the importance not only of this book but of any book that is written today.

In some reactions to my book there is an element of sexism as well. When a man issues an opinion, people are o.k. with it. There's a sense that he has an authority. Whereas when you are a woman, they do not like it: they do not like your confidence.

I wrote Transwonderland in the first person: it is my feelings, it is a very subjective book. I make it very clear when I do not understand certain things. But if I make an observation, I just make it and I expect the reader to understand that it is my personal one. I did not write a book about Nigeria: I wrote a book about my journey around Nigeria. Travel writing has always been subjective. When I read any travel book, I always have that in mind. When you are reading books, for example, by certain white men in the 1970s, they have typical white male interests. So you know that and you think, o.k., that is this guy's way of looking at things. And you take everything with a pinch of salt. I expected the same with my book. But travel literature is not common in Nigeria; it is a kind of a genre that is not familiar to readers.

I hate this idea of using identity as a criterion for allowing people to do and say things. This is madness. In the creative world there are no rules. Nigerians often complain about ethnic divisions, tribalism and all these things. But then, when my book came out, certain commentators became very tribal, suggesting that I was not allowed to say certain things because I belong to the "Diasporan tribe". If somebody insisted you could not do something because you are a woman or because you are a man, people would be outraged. In the same way, it is really strange when people discredit your opinion on the basis of your supposed identity.

by Roberto ZAUGG

Université de Lausanne

Lausanne, 7 April 2017 


\section{BIBLIOGRAPHY}

Achebe, Chinua, Things fall apart, London, Heinemann, 1958.

Adichie, Chiamanda Ngozi, Americanah, New York, Knopf, 2013.

Appiah, Kwame Anthony, "Whose culture is it?", in Whose culture? The promise of Museums and the debate over Antiquities, ed. by James B. Cuno, Princeton, Princeton UP, 2009, p. 71-86.

CÉsaire, Aimé, "Cahier d'un retour au pays natal", Volontés, 20 (August 1939), p. 23-51.

Saro-Wiwa, Noo, Looking for Transwonderland. Travels in Nigeria, London, Granta, 2013, (French transl. : Transwonderland. Retour au Nigéria, Paris, Hoëbeke, 2013; Italian transl.: In cerca di Transwonderland. Il mio viaggio in Nigeria, Roma, 66th and 2nd, 2015).

—, "A time to lie", in A country of refuge. An anthology of writing on asylum seekers, ed. by Lucy Popescu, London, Unbound, 2016, p. 125-132.

-, "Soft on the inside", in An unreliable guide to London, ed. by Gary Budden and Kit Caless, London, Influx, 2016, p. 150-163.

Selasie, Tayie, Ghana must go, New York, Penguin, 2013. 